Mavi Atlas, 8(2)2020: 507-516

Makale Geliș | Received: 01.09.2020.

Makale Kabul | Accepted: 28.09.2020.

DOI: $10.18795 /$ gumusmaviatlas. 789119

Osman ORUÇ

Dr.Öğr.Üyesi|Asst. Prof. Dr.

Bayburt Üniversitesi, İnsan ve Toplum Bilimleri Fakültesi, Türk Dili ve Edebiyatı Bölümü, Bayburt-TÜRKIYE Bayburt University,Faculty of Humanities and Public, Dep. of Turkish Language and Literature, Bayburt-TURKEY

ORCID: 0000-0002-2610-185X

osmanoruc@bayburt.edu.tr

\title{
Orhan Kemal'in Bereketli Topraklar Üzerinde ve Gurbet Kuşları Adlı Romanlarında Taşralı İnsanın Değişim Süreci
}

$\ddot{O} z$

Orhan Kemal, 1950'li yıllardan itibaren ivme kazanan köyden kente göç olgusunu ve kapitalist ekonomik yapılaşmanın dayattığ gerçekliği romanlarında ele alan, bu bağlamda taşralı bireyin büyük kentte yaşadığı açmazları, sıkıntıları, değişim ve dönüşümü, yabancılaşma gerçeğini ve bir kimlik inşa etme süreçlerini enine boyuna irdeleyen belli başlı toplumcugerçekçi romancılarımızdan birisidir. Bizatihi kendisinin de tecrübe etmiş yahut yakından tanıklık etmiş olduğu toprak ve fabrika işçilerinin hayatlarını, köyden büyük kentlere göç eden gurbetçilerin yaşam mücadelelerini son derece gerçekçi ve bir o kadar samimi bir duyarlıkla kaleme alan Orhan Kemal, bu yönüyle Türk edebiyatında "yaşadıklarını yazan" bir sanatçı hüviyetiyle nev-i şahsına münhasır bir yer edinmiştir.

Tarım sektöründe gözlenen endüstrileşme ile birlikte doğduğu topraklarda geçinme ve yaşama imkânı kalmayan taşralı insanın yeni bir hayat düzeni kurmak umuduyla kente göç etmesi, sonrasında burada tutunma çabaları, yazarın birbirinin devamı niteliğinde olan Bereketli Topraklar Ǚ̌rinde ve Gurbet Kuşlarzadlı romanlarında masaya yatırlan problemlerdendir. Yazar, her iki romanda da, yaşadıkları köyün dışına çıkmamış, dolayısıyla kente ve kentlilere yabancı taşralı bireyin, kendisi için adeta büyük bir kaos ortamı olan şehirde yalpalaması, nesneleşmesi, kendine ve topluma yabancilaşması, insanî erdemlerin uzağında kalması, değerler dizgesinin alt üst olması vb. süreçleri ortaya serer. Bu çalş̧mada, yazarın bahse konu iki romanı odağa alınarak yukarıda sözü edilen değişim süreçleri açığa çıkarılmaya çalışlacaktır.

Anahtar Kelimeler: Orhan Kemal, Göç, Yabancılaşma, Değişim, Dönüşüm.

\section{The Change Process of the Rural People in Orhan Kemal's Novels titled On Fertile Lands (Bereketli Topraklar Üzerinde) and Birds of Exile (Gurbet Kuşlart)}

\begin{abstract}
Orhan Kemal is one of our socialist-realistic novelists examining the phenomenon of migration from rural to urban areas, which have accelerated ever since 1950s, and the reality imposed by the capitalist economic structure, and telling the problems of rural people such as dilemmas, troubles, change and transformation, alienation and building an identity. Orhan Kemal wrote about the lives of the land and factory workers, which he personally experienced or closely witnessed, and the life struggles of the expatriates, who have migrated from the rural to urban areas, with such realism and sincerity; thus, he was known as the author with the artistic identity by "writing on what he experienced" and gained a unique place in the Turkish literature.

The migration of the rural people, who have no opportunity to live and earn income in their birthplace together with the industrialization observed in the agricultural sector, to urban areas in the hope of establishing a new life order and their efforts to hold onto life here are the problems examined in the novels of the author titled On Fertile Lands (Bereketli Topraklar Üzerinde) and Birds of Exile (Gurbet Kuslarr), which is considered as a sequel to the first novel. In both novels, the author demonstrates the processes undergone by rural people, who have not left their village before and therefore do not know anything about the cities and the city people, such as staggering in the total chaos environment of the city, objectification, alienating to themselves and to the society, drifting away from the human virtues and being upside down in terms of values. In this study, the change processes mentioned above will be tried to be revealed by focusing on the two related novels of the author.
\end{abstract}

Keywords: Orhan Kemal, Migration, Alienation, Change, Transformation. 


\section{ORUÇ, Osman (2020). “Orhan Kemal'in Bereketli Topraklar Üzerinde ve Gurbet Kuşları Adlı Romanlarında Taşralı İnsanın Değişim Süreci”, Mavi Atlas, 8(2): 507-516}

\section{Giriş}

Berna Moran'ın ifadesiyle Türk romanı tematik anlamda, başlangıcından Kuyucaklı Yusuf'a kadar Doğu-Batı meselesi, 1950'li yıllardan itibaren sınıf çatışmaları/toplumsal gerçekçilik, 1980 sonrasında ise postmodernizm/yazınsal gerçekçilik ekseninde bir seyir izler (Moran, 2012a: 9-24). $\mathrm{Bu}$ bağlamda eserlerini yoğun olarak 1950'li yıllardan itibaren kaleme alan Orhan Kemal, yapıtlarının çoğunda kendisinin de dâhil olduğu ve bu açıdan yakından tanık olduğu işçi çevrelerinin sorunlarını, emekçilerin sermaye ve toprak sahipleriyle ilişkilerini/çatışmalarını ele alır.

Romancının yazıya konu olan iki romanında da göç hadisesi geçim mücadelesinin bir sonucu olarak karşımıza çıkar. İflahsızın Yusuf ve arkadaşlarıyla İflahsızın Memed'i yurtlarını terk etmek mecburiyetinde bırakan bu gerçektir. Dolayısıyla bu yer değiştirme gönüllü değil, aksine zorunlu bir eylemdir. Onları göçe zorlayan maddi bir kayıttır ve bu yüzden gittikleri yerlerde bu maddi kaydı gidermenin çabasını verirler. Hayatta kalma savaşı maddi olanı öne çıkarırken insanın iç dünyasına ait olan kıymetler sürekli bir biçimde geri planda kalır. Bu durum insanî olan her şeyin zamanla aşınmasına ve son tahlilde yok olmasına zemin hazırlar. "Metanın mantığ günümüzde sadece emek süreçlerini ve maddi ürünleri değil, tüm kültürü, cinselliği, tüm insanî ilişkileri, bireysel fantezilere ve itkilere kadar, denetimi altına alarak genelleşti" (Baudrillard, 2017: 251). Roman kahramanları arasındaki gündelik ilişkilerden aşka kadar bütün duygular maddi boyutta kalır. $\mathrm{Bu}$ maddi boyutu 'ekmek kavgası' ifadesiyle özetleyebiliriz. Kahramanlar roman boyunca hayatta kalmanın, geçinmenin kavgasını verirken doğal olarak birbirleriyle mücadele haline girerler. Ekmeğe ulaşmak adına verilen bu savaşta başta birlikte yola çıkan bireylerin arası giderek açılır, çıkar düşüncesi onları insanî olandan uzaklaştırırken nesnenin/metanın kölesi yapar.

Ekmek kavgası ve emeğin sömürüsü her iki romanda da ele alınan başat konulardır ve bunlar roman kahramanlarının büyük şehirlerdeki kaderlerini tayin eder. Koşulların biçimlendirdiği kişilikler olarak ortaya çıkan roman kahramanlanı, aç karınlarını doyurmak pahasına kapitalist iş sahiplerinin köleleri olmayı yeğlerler. "İşsiz kalma korkusunun ağır basması nedeniyle içlerinden konuşurlar" (Kurdakul, 2005: 155-156). Böylece kendilerini inkâr etme yolunu seçerler ve insanî değerlerin üzerine basa basa yollarına devam ederler. Emekleri büyük toprak sahipleri/zenginler tarafindan sömürülen bu küçük insanlar emeklerinin karşıllğıını sormazlar. Patronların servetlerine servet katmaları, işçilerin daha çok çalışması, daha çok ezilmesi, emeklerinin daha çok sömürülmesiyle koşuttur. Başka türlü hayatta kalma imkânı olmayan emekçiler, öğrenilmiş çaresizlik psikolojisi içinde patronun çıkarına fakat kendi zararlarına çalışmaya devam ederler. "Koşulların çıkmaza soktuğu" (Kurdakul, 2005: 158) işçiler, patron namına üretim çarkının dişlileri arasında kendilerini tüketirler.

\section{Bereketli Topraklar Üzerinde Çoraklaşan İnsan}

Sivas'ın Ç.Köyü'nden 'kardeşten ileri' üç arkadaş; İflahsızın Yusuf, Köse Hasan ve Pehlivan Ali çalışmak üzere Çukurova'ya gitmeye karar verirler. Bu üç arkadaş köyde kapı komşusudur ve çocuklukları bir arada geçmiştir. Köse Hasan ve Pehlivan Ali ilk kez şehre gitmektedirler. İflahsızın Yusuf ise öncesinde Sivas'a gitmiştir. Bu bakımdan o, iki arkadaşına nispeten Çukurova'ya daha hazırlıklı gider. Ayrıca İflahsızın Yusuf, Çukurova'da uzun süre çalışmış emmisinin ögü̈tlerini de kuşanmıştır. Bu açıdan o, tutunmak için şehirde nasıl hareket edeceğinin az çok malumatıyla yola çıkar. Her adımında emmisinin ögütlerini hatırlar ve bu ögütlere göre hareketlerini belirler. Köye üç saat mesafedeki tren istasyonuna gece yarısı varırlar.

Üç arkadaş gece yarısı vardılar istasyona. Kaba bir rüzgâr ortalı̆̆ alt üst ediyordu. Yukarda da öfkeli, kapkara bulutlar (Orhan Kemal, 2013a: 2).

Bu kapalı/karanlık atmosfer, bu üç arkadaşın sonradan Çukurova'da yaşayacaklarının ön habercisi gibidir. Ifflahsızın Yusuf yola çıkarken ssrarla arkadaşlarını cesaretlendirir, birlikte hareket ettikten sonra gittikleri yerde karşılaşacakları muhtemel bütün zorlukların altından kalkacaklarından 


\section{ORUÇ, Osman (2020). “Orhan Kemal'in Bereketli Topraklar Üzerinde ve Gurbet Kuşları Adlı Romanlarında Taşralı İnsanın Değişim Süreci”, Mavi Atlas, 8(2): 507-516}

söz eder. Yusuf 'un bu tavrı, romanın ilerleyen safhalarında görüleceği üzere arkadaşlık hukukunu gözetmekten ziyade, emmisinden kendisine tevarüs eden pragmatist kişiliğinden kaynaklanır. Zira kendisi de büyük şehirde ayaklarını yere sağlam basacağı ana dek, diğer iki arkadaşına muhtaçtır. Nitekim belli bir zaman sonra her iki arkadaşından da kurtulmanın yolunu arayacaktır. Bununla birlikte başta İflahsızın Yusuf olmak üzere üç arkadașın da daha yolun başında șehirlileri düşman imgesiyle algılamaları, kendilerini bir arada tutacak bir düşman yaratma ihtiyacıyla alakalıdır. Kendilerinin 'ne olduklarının bilgisine' ulaşmak bir düşmanın varllğı ile mümkün olacaktır. Bu anlamda daha istasyonda kendilerini Çukurova'ya götürecek treni beklerken bir düşman yaratmış olurlar. Zira "Düşman sahibi olmak sadece kimliğimizi tanımlama açısından değil, aynı zamanda kendi değer sistemimizi ölçebilmek için bir engel edinmek ve o engelle yüzleşirken kendi değerimizi sergilemek açısından da önemlidir. Dolayısıyla düşman yoksa onu inşa etmek gereklidir" (Eco, 2014:16). Üç arkadaşın şehirlileri düşman/öteki olarak konumlandırmaları, aralarında bir ortak bağ/değer tesis etmeye yönelik bir girişimdir. Bu girişim şehirde tesis edecekleri yeni düzen ve çalışma koşullarının muhtemel sonucu olarak "herkesi herkes ile karşı karşıya getiren çıkar farkl11ıkları ortaya çıtığında sistemi neyin bir arada tutacağ1" (Giddens, 2016: 21) sorusuna cevap hükmünde bir tavırdır. Şehirliler farklıdır ve bu yüzden tehditkârdırlar. Bu tehdit unsuruna karşı bir arada olmak zorundadırlar.

İflahsızın Yusuf "şehir adamı bir cin" ifadesini romanın başka sayfalarında da tekrar eder. Bu bir bakıma, Yusuf'un Çukurova'daki yaşama, orada karşılaşacağı güçlüklere kendini hazırlama tarzıdır. Böylece orada vereceği mücadelede, bir düşman inşa ederek bir iç motivasyon sağlamış olur. Emmisinin öğ̈̈tlerini kendisine rehber edinen İflahsızın Yusufla Pehlivan Ali arasındaki kişilik farkı da yine romanın başında sezilir. Para/metaya sahip olmak uğruna şahsiyetini iş sahiplerinin ayaklanı altına sermekten geri durmayan bu amca-yeğen ikilisinin tersine Pehlivan Ali'de yer yer insanî olanin sesi duyulur.

"Emmim derdi ki, siz siz olun şehirlinin suyuna göre gidin, şehirli ak derse siz kara demeyin derdi."

"Şehirlinin ak dediği karaysa ya?"

"Olsun."

"Ben demem!"

"Emmim derdi Ali, hani emmim vardı ya, Dudu Ablamın eri?"

Köse Hasan, Pehlivan Ali'yi dirseğiyle dürttü. Ali yine de kesti attı:

"Ben demem!" (Orhan Kemal, 2013a: 35).

Meta karşısında alınan bu farklı tavırlar Pehlivan Ali'nin ve İflahsızın Yusufun Çukurova'daki kaderlerini de belirler. İflahsızın Yusuf, metaya (para, gaz ocağı) sahip olmayı hayatının merkezine yerleştirmiş ve bu amaç uğrunda düzenin arzu ettiği bir felsefe doğrultusunda hareket etmiştir. Metaya sahip olmak hayatla eşdeğer bir konumdadır. Pehlivan Ali bu noktada arkadaşından epeyce ayrılır. O, düzenin buyruklarını kulak ardı eder ve kendi insiyaklarının peşinden gider. Onun eylemlerini erkeklik içgüdüleri biçimlendirirken, arkadaşı İflahsızın Yusuf kapitalist düzenin arzu ettiği bir hareket tarzını benimser. İki arkadaşın düzen ve meta karşısındaki farklı tutumları, yine düzen/kapitalist sistem tarafindan ödül ve ceza mekanizmaları devreye sokularak karşılık bulur. İflahsızın Yusuf düzenle uyumlu konformist birey olmanın ödülü paraya ve gaz ocağına sahip olarak memleketine dönmeyi başarırken, Pehlivan Ali düzen karşıtı eylemleriyle, düzenin araçlarından patoz makinesine ayağını kaptırarak ölür.

Öte yandan romanın hemen başında yazar, Köse Hasan ve Pehlivan Ali'nin ahlakî bakımdan nasıl kişilikler olduğunu da haber verir. Bu iki arkadaş köyde, İflahsızın Yusuf'un emmisinin karısını derede çerçiyle basmışlardır ve şahit oldukları bu manzaradan rahatsız olmak ve bu eylemin faillerini kınamak yerine, bunu bir tehdit aracı olarak kullanıp ellerine geçen bu firsattan istifade etme yoluna 


\section{ORUÇ, Osman (2020). “Orhan Kemal'in Bereketli Topraklar Üzerinde ve Gurbet Kuşları Adlı Romanlarında Taşralı İnsanın Değişim Süreci”, Mavi Atlas, 8(2): 507-516}

gitmişlerdir. Orhan Kemal'in romanın daha ilk sayfalarında bu pasajları sunması, roman karakterlerinin nasıl insanlar olduğuna dair okuyucuya epeyce bir malumat verir.

İflahsızın Yusuf bir nesneye sahip olmak arzusuyla yola çıkar. Bu nesne "gazocağı"dır. Bu nesneye sahip olarak köyüne geri dönmek Yusuf'a bir kimlik kazandıracaktır. Bu durum bize Vladimir Propp'un Masalın Biçimbilimi adlı eserinde tespit etmiş olduğu ve büyük ölçüde bütün anlatılarda karşımıza çıkan otuz bir dizgeden birini düşündürür. Bu dizgeye göre "aileden birinin bir eksiği vardır; aileden biri bir şeyi elde etmek ister" (Propp, 2017: 37). İflahsızın Yusuf da bu amaçla yola çıkar. Bunun yanında aynı dizgede dile getirilen para yokluğu, gelir yokluğu da hem İflahsız Yusufun hem de iki arkadaşının köylerinden ayrılma nedenleridir. İflahsızın Yusuf, arkadaşlarına gazocağını anlatırken adeta gizemli/büyülü bir nesneden söz eder.

"Köyün besleyemediği, toprağın şehre, yani işe ve ekmeğe ittiği köylüler" (Fethi Naci, 2012: 299), önceleri hemşerilerinin çırçır fabrikasında iş tutarlar. Ancak Köse Hasan çalışma koşullarının ağırlığına daha fazla dayanamaz, hastalanır ve yataktan çıkamaz hale düşer. Bu durum onun fabrikadan çıkarılmasına neden olur. Bu dakikadan itibaren Köse Hasan, arkadaşları İflahsızın Yusuf ve Pehlivan Ali için bir yük halini alır. Köse Hasan'ın hastalığı ile pek alakadar olmazlar. Aralarına yabancılık girmeye başlar. Para kazanma, geçim derdi ve hayatta kalma kaygısı arkadaşlıklarının önüne geçer. Beraber geldikleri Çukurova'da bu birliktelikleri bozulmaya başlar. “ 'Anca beraber, kanca beraber' diyen üç arkadaş birbirinden ayrılır, hiçbiri ötekiyle ilgilenmez, birlikte iş aramaya çıktıkları köylülerini ölüme terk ederler” (Fethi Naci, 2012: 301).

Çırçır fabrikasından bir uyuşmazlık yüzünden ayrılırlar ve inşaatta çalışmaya başlarlar. Köse Hasan'ı kendi başına bırakırlar. Pehlivan Ali inşaattaki işçilerden birinin karısı olan Fatma'nın peşine takılır. Yatağını ve eşyalarını toplayarak İflahsızın Yusufun yanından ayrılır. Fatma ve kocası Ömer Zorlu'nun kaldıkları odaya taşınır. Böylece birlikte yola çıkan üç arkadaştan her biri tek başına kalmış olur.

Köyden güya o sözle çıttık. Anca beraber, kanca beraber. Biz esas üç arkadaştık. Üçümüz de bir köylüyüz. Çukurova'ya beraber indik. Hani üçümüz de kardaştan ileriydik. Şurda bir fabrika var, bizim hemşerilerin fabrikası. Bizim köyden değil ya, bizim sancaktan olur sahibi. Fabrikasının çırçırlarında çalışıyorduk, barındırmadılar bizi gözleri çıssın. Güya hemşerimiz. Hemșeri memșeri fosmuș meğer. Herif tomofiline kasıllp gidiyor. Bilmeyen vali beller. Hemşeri umurunda mı? Onu diyecektim, bir de arkadaşımız vardı, adı Köse Hasan. O, ben, bir de bu Ali. Üçümüz beraber gider gelirdik işe, bekâr ahırında da yatar kalkardık. (Orhan Kemal, 2013a: 139).

Orhan Kemal'in, yukarıda emekçileri bir ahırda barındırması boşuna değildir. Zira sermaye sahiplerinin nazarında bu küçük insanlar, adeta hayvanlar gibi "sahiplerinin" faydasına çalışan canlılar, onlar adına işleyen makinelerden farksızdırlar. Bu anlamda romancı, bu üç arkadaşı insanların değil, hayvanların yaşadığı mekânda okuyucunun dikkatine sunar.

İflahsızın Yusuf, Kılıç Usta'nın yanında duvar ustası olur. Bu arada Köse Hasan ölür. İflahsızın Yusuf bu haberi çok sonra, Hidayet'in oğlu diye anılan üçüncü bir kişinin ağzından öğrenir. Hidayet’in oğlu da Yusuf ve Ali’nin arkadaşlarına karşı ilgisizliklerini yadırgar.

Yusuf ağlıyordu, duymadı. Hidayet'in oğlu, 'Hiç arayıp sormadınız fukarayı', dedi.

'Hemşerilik böyle mi olur?' (Orhan Kemal, 2013a: 157).

Pehlivan Ali, inşaat işinde de tutunamaz ve Ömer Zorlu'nun karısıyla kaçar. Tarlalarda çalışmaya başlar. Ancak burada da kötü gidişe dur diyemez, Fatma'yı kaybeder. Patoz makinesinde bacağını yitirir ve kan kaybından ölür.

Ç.'den bereketli topraklara umutlarının peşinden yaptıkları yolculuk hüsranla neticelenir. Çukurova'nın sıcağında gerçekliğin katlanılmaz ağırlı̆̆ı altında üç arkadaştan ikisi hayata yenik düşerler. Köse Hasan tek başına bir hastane köşesinde, Pehlivan Ali de tarlada hayata gözlerini 


\section{ORUÇ, Osman (2020). “Orhan Kemal'in Bereketli Topraklar Üzerinde ve Gurbet Kuşları Adlı Romanlarında Taşralı İnsanın Değişim Süreci”, Mavi Atlas, 8(2): 507-516}

kapatır. İflahsızın Yusuf ise aklından çıkarmadığ1 amcasının ögütlerinin de yardımıyla hayatta kalmayı ve köyüne dönmeyi başarır. Köyüne dönmek üzere tren istasyonuna gelen Yusufun kendine olan güvenini içeren sözleri onun, 'insanî erdemleri dışarıda tutarak' ifade edersek savrulmadan, kaybolmadan hayatta kalmayı başarmış bir kişilik kazandığını açık eder.

Lacivert elbiseli bir istasyon memuruna sokuldu:

'Ben duvar ustasiylm,' dedi. 'Sivas treni hangisi?'

Ufak tefek, şakacı biri olan istasyon memuru, 'Nesin nesin?’ diye sordu.

Yusuf hep o gururla, 'Duvar ustas1!' dedi. (Orhan Kemal, 2013a: 359).

Yusuf elinde bavul istasyon binasinda ilerlerken duvar ustası olmanın bütün gururunu üzerinde taşır. Çukurova'da şahsiyetine eklediği kazanımları bir bir sayar ve böylelikle yeni kimliğini ortaya koymuş olur.

Yusuf aralarından gururla geçiyordu. Bunca insanlardan hangisi kendisi gibi duvar ustalığını belleyebilmişti? Koyunlarında kaç para vardı? Okuma yazma bellemişler miydi? Yazmayı pek beceremiyordu amma, gelecek y1l onu da belleyecekti, yemin etmişti. (Orhan Kemal, 2013a: 366).

Ağır çalışma koşullarında emekleri sömürülen üç arkadaştan ikisi çırçır fabrikasında ve Çukurova'nın uçsuz bucaksız tarlalarında tükenirler. "(...) Bu roman üç köylüden ikisinin niteliksiz yığınlardan farksız bir şekilde, onların ortak kaderini paylaşarak yenilgisini anlatırken, nitelikli iş̧ sahibi olan, usta olan bireylerin, bu süreçte nasıl ayakta kaldıklarının da anlatımına dönüşür" (Gültekin, 2006: 127). Hayatta kalma mücadelesinde üç arkadaş ayrı düşer, birbirlerine yabancılaşır ve her biri bir tarafa savrulur. Bu savrulmadan kurtulan ve Çukurova'nın acımasız çalışma koşullarında ayakta kalabilen tek kişi İflahsızın Yusuf olur.

Attığı her adımda emmisinin öğütlerine uyan İflahsızın Yusuf, şehir yerinde ayakta kalma adına aşağılanmayı göze alır, terslenir, tokatlanır, onurundan ödün vermekten çekinmez, bireysel çıkarı için daima alttan alır ve böylece gemisini yürütür. Arkadaşından ayrı bir hareket tarzı benimseyen, düzenin dişına çıkan Pehlivan Ali ise bu tercihini hayatıyla öder. Ağır çalışma koşullarına dayanamayan, bedensel olarak zayıf, dolayısıyla iş sahiplerince faydasız bir kişi olan Köse Hasan ölür. Bu bağlamda kapitalist üretim çarklarının bedensel anlamda zayıf/kullanışsız ve düzenin buyruklarına itaat etmeyen işçileri dışladığı/cezalandırdığı, aksine düzenle her hangi bir sorun yaşamayan işçileri ödüllendirdiği görülür.

Köyden herhangi bir vasfı olmayan bir durumda ayrılan Yusuf, Çukurova'dan dönerken vasıflı bir inşaat işçisidir. Çukurova'da geçirdiği zaman zarfında, yukarıda sözü edilen 'maddi kaydı' gidermiş, böylelikle şahsiyetinin eksik olan tarafını tamamlamıştır.

Bereketli Topraklar Üzerinde'nin olay örgüsü dünya anlatı edebiyatında çok kullanılmış olan bir yolculuk üzerine kurulmuştur. Mitoslardan kaynaklanan, destanlara, romanslara ve arama arketipini izleyen masallara geçmiş olan bu kurgu, ayrılış-savaşım-dönüş kalıplarından oluşur.

(...) Bereketli Topraklar Üzerinde'nin olay örgüsü de, temelde aynı yapıy1 gösterir. Üç arkadaş yoksulluk (kıtlık) yüzünden köyden ayrilır, yola çıkarlar. İstedikleri nesnenin (paranın) bulunduğu kente varırlar. Kentte türlü güçlüklerle karşılaşırlar ve cinlerle özdeşleştirdikleri şehirlilere karşı verdikleri savaşım sonucu üç arkadaştan ikisi ölür, yalnız biri savaşımı kazanır, amaçladıklarını elde ederek köyüne döner ve ailesine bolluk getirir. (Moran, 2012b: 49-50).

Sivas'in Ç. Köyü'nden Çukurova'ya doğru yola çıkan Yusuf'la Çukurova'dan köyüne dönen Yusuf farklıdır. Yolculuk tecrübesinden sonra yeni sıfatlar kazanmıştır. Artık o bir duvar ustasıdır, 


\section{ORUÇ, Osman (2020). “Orhan Kemal'in Bereketli Topraklar Üzerinde ve Gurbet Kuşları Adlı Romanlarında Taşralı İnsanın Değişim Süreci”, Mavi Atlas, 8(2): 507-516}

cebinde parası vardır ve şehirlilere baktığ1 nokta çok daha farklıdır. İlk geldiğinde 'cin' olarak gördüğü şehirliler, şimdi onun gözünde birer 'enayi'dirler.

"Yolculuğu tamamlayabilen ve köyüne elinde gaz ocağı ile bir masal kahramanı gibi dönen Yusuf, arkadaşları gibi ezilmemiş, tersine usta mertebesine ulaşmayı başarmış, okumayı da sökmüş bir köylü"dür (Moran, 2012b: 69) artık. Bununla birlikte o, kişisel çıkarın rehberlik ettiği Çukurova macerasının sonunda insanî değer adına ne varsa hepsini yitirmiş ve bu anlamda kendisine yabancılaşmıştır. Emeğin yarattığı nesneler dünyasının egemenliğine giren Yusuf, emek aracıllğı̆la kendi kendini gerçekleştiren insanî özden uzak düştüğü için bir bakıma kendi varlığını reddetmiş olur. Yabancilaşan insan "kendisinin tersine dönen, kötülüğe ve kendisinin düșmanına dönüșen, kendisini kendisine karşı kışkırtan bir insan"dır (Baudrillard, 2017: 249).Bu bağlamda İflahsızın Yusuf, amacına ulaşma uğruna kendilik kodlarından ödün vermiş, işs sahiplerine dalkavukluk etmiş, bir bakıma "şeytanla pazarlık" (Baudrillard, 2017: 250) yapmış, kişisel menfaatini insanî erdemlerden üstün tutarak yozlaşmıştır. Bu anlamda para/metaya, sahip olma, refaha ulaşma amacıyla yola çıkan birey, bu yolculuğun sonunda meta tarafından ele geçirilmiş ve böylece özne nesneleşmiştir.

\section{Büyük Şehirde Yiten Küçük İnsan: Gurbet Kuşları}

Köyden kente göç dalgasının bütün ülkeyi sardığı 1950'li yıllarda İflahsızların Memed ve sonrasında bütün aile, daha rahat bir hayata erişmek ve zengin olmak hayaliyle İstanbul'a göç ederler. İflahsızların Memed, İstanbul'daki anne tarafindan uzaktan akrabası Gafur'un cesaretlendirmesiyle çalışıp bir baltaya sap olmak, gemisini yürütmek üzere Kurtalan-Haydarpaşa treniyle Sivas'tan İstanbul'a gelir. Haydarpaşa'da trenden indikten itibaren istasyon binasından başlayarak vapurda, köprüde ve sokaklarda şehirliler tarafından aşağılayıcı muamelelere maruz kalır.

Çevrelerine yenik, şaşkın, mahcup, korkak bakışları, yeşil, sarı, mor, kırmızıları kirli çorapları, kirli tırnaklarıyla etlerini hart hart kaşıyışlarıyla garın geniş betonuna bir sığır 1lıklığılla yayılmış, kalabalıkla, kalabalı̆̆ın arasında ağır ağır sürükleniyorlardı garın çıkış kapisina.

'Ayılara hele ayılara!'

'Șerefsizim sürü!'

'Her gün bu, her gün bu. Köylerinden ne diye ürkütürler bu hayvanları bilmem ki?' (Orhan Kemal, 2013b: 2-3).

Romanc1, Bereketli Topraklar Üzerinde'de olduğu gibi bu romanda da emek işçilerini "hayvan" imgesiyle ele alır. Bereketli Topraklar Üzerinde romanında işçilerin kaldığ1 mekân bir ahırdır. $\mathrm{Bu}$ romanda mekân bağlamında "hayvan" imgesini vurgulayan Orhan Kemal, Gurbet Kuşları romanında doğrudan "sığır" sözcüğüyle taşradan büyük kente çalısmaya gelen emekçilerin şehirli indindeki değer(sizlik)lerini açığa çıkarmış olur.

Köylülerine söylediği gibi aslında bir 'kabzımal' değil, sadece Kabzımal Hüseyin Korkmaz'in dükkânında çalışan sıradan bir işçi olan Gafur, önceden köye yazdığı mektupta söz vermesine rağmen Memed'le oralı olmaz, ilgilenmez. Bunun üzerine Memed, meyve halinde çalışan Hamal Veli'nin yardımıyla Küçükpazar'da kalabalık bir bekâr evinde kalmaya başlar. Burada inşaat yıkımı üzerine bir iş bulur ve çalışmaya başlar. Sonradan Kabzımal Hüseyin Korkmaz'ın evinde hizmetçilik eden Ayşe ile tanışır ve ardından evlenirler. Bir süre Memed ve Ayşe, Kabzımal Hüseyin Bey’in köşkünün müştemilat bölümünde yaşarlar. Çıraklıktan, duvar ustalığına terfi eden, oradan da Kabzımal Hüseyin Korkmaz’ın gözüne girmesiyle kabzımal dükkânında çalışmaya başlayan İflahsızların Memed, memleketteki babasına, İstanbul'da her şeyin yolunda gittiğinden, işlerin çokluğundan, para kazanmanın kolaylığından söz eden bir mektup yazar. Okuma yazmayı söktüğü için kendi el yazısıyla yazdığı bu mektupla, babası Ifflahsızların Yusufu bütün ailesiyle birlikte İstanbul'a davet eder. 


\section{ORUÇ, Osman (2020). “Orhan Kemal'in Bereketli Topraklar Üzerinde ve Gurbet Kuşları Adlı Romanlarında Taşralı İnsanın Değişim Süreci”, Mavi Atlas, 8(2): 507-516}

Babası ve kardeşleri İstanbul'a geldikten sonra Memed'in hayatı değişir, işler sarpa sarmaya başlar. İflahsızların Yusuf, oğlunun İstanbul'da değiştiğini, başka başka huylar edindiğini görür ve bu yüzden onunla anlaşamaz. Memed ve Ayşe köşsten ayrılır, Zeytinburnu'nda tek göz kiralık bir evde yaşamaya başlarlar ve daha sonra küçük bir arsa alarak, bir buçuk odalı küçük bir gecekondu yapmanın mücadelesine girişirler. Esasen bu gecekondu inşa etme işi örtük bir biçimde İflahsızın Memed'in hayatla ve düzenle savaşımını da işaret eder.

Gurbet Kuşlar romanında taşradan büyük kente göç sonrasında değişim üç birey üzerinde gözlenir. Merkezde İflahsızların Memed olmak üzere, onun kız kardeşi Ümmü ve Kabzımal Müteahhit Hüseyin Korkmaz. Bu süreçte cahil, okuma yazma bilmeyen Memed şuurlu bir işçiye, emekçiye dönüşürken, kız kardeşi Ümmü utangaç köylü kızından şuh bir genç kıza evrilir. Bu iki roman kahramanından çok önce, taşradan İstanbul'a gelmiş olan Hüseyin Korkmaz'daki değişim ise şekil boyutundan öteye geçemez.

Taşrada yaşayanlar için İstanbul bir kurtuluş umududur. İstanbul'a çalışmaya gidip bir süre sonra memleketlerine dönenler, onların bu umudunu besler. Zira İstanbul'a gidenlerle geri gelenler adeta başka insanlardır.

Ne yapıp yapıp gidenler, birkaç ay sonra değişmiş dönüyorlardı. Taralı saçları, kopçalı sarı kalemleri, karton kaplı cep defterleri, arkaları çıplak kadın resimli cep aynaları, Tahtakale'den uydurulmuş üst başlarıyla köy yerinde dolanıyor, köy kahvelerinde, delikanlı meclislerinde İstanbul'u dillerinden düşürmüyorlardı. İstanbul da bir İstanbul'du. Dil ile tarifi mümkünsüz. O taksiler, o dolmuşlar, o tramvaylar, otobüsler, vapurlar... (Orhan Kemal, 2013b: 2).

Önce 'Kabzımal Hüseyin Korkmaz' iken, sonradan karısının politikacılarla yakın ilişkisinin yardımıyla müteahhitliğe terfi eden Hüseyin Korkmaz, Niğde'nin köylüğünden İstanbul'a gelmiştir. Şimdi kendisinin olan kabzımal dükkânında bir hamal olarak çalısmaya başlamış, sonradan yaşlı dükkân sahibinin genç karısıyla yakınlaşmıs, patronunun ölmesiyle de karısıyla birlikte bütün mal varlığ1 Hüseyin'e kalmıştır. Böylece o, işçilikten kabzımallığa, oradan da müteahhitliğe kadar yükselmiştir. Fakat Hüseyin Korkmaz'1n elde ettiği bütün bu maddi kazanç emeğinin sonucu değil, tam tersine gayri ahlaki bir hayat görüşünün semeresidir. Bununla birlikte karısının zoruyla satın alıp giydiği İngiliz kupon kumaşından elbiseleri içinde rahat değildir. 'İngiliz kupon kumaşı giydirilmiş Anadoluluğu’ müsait olduğu her firsatta kendini açık eder. Karısının tesiriyle şekli olarak şehirli bir adam gibi görünen Hüseyin Korkmaz, köylülükten bir türlü kurtulamaz. O, karısının zoruyla bir dönüşüme tabi tutulur, ancak bu dönüşüm hiçbir zaman gerçek manada içselleştirilmiş bir dönüşüm olmaz. Memleketindeki dere boyu, dere boyunun ceviz gölgesini hiçbir zaman unutamaz. Karısının yokluğunda evin hizmetçisi Ayşe’ye 'Anşa' diye hitap eder ve ondan bol soğanlı bulgur pilavı pişirmesini ve yer sofrasını hazırlamasını ister. Kendisi de karısının giymeyi yasak ettiği beyaz gecelik entarisini giyer.

Ya hanım Ankara'dayken koşup gelerek bulgur pilavı isteyişi? Karısının giymeyi yasak ettiği beyaz gecelik entarisini bulup giyişi! (Orhan Kemal, 2013b: 191).

Kabzımal Hüseyin Korkmaz menfaat düşkünü bir taşralıdır. O, menfaati uğruna patronunu aldatmış, karısına ve bütün mülküne sahip olmuştur. Şimdi de daha genç ikinci karısının kaprislerine yine kişisel çıkarları için katlanmaktadır. Gerçi karısı karşısında edilgen bir konumdadır ancak el altından kendi hayat felsefesi doğrultusunda işlerini yürütmektedir. Karısının, kendisini şehirli yapma dayatmalarına alttan alta direnmektedir. Karısının üzerine giydirmeye çalıştı̆ı şehirli kimliği onu rahatsiz eder.

Tuttu bana İngiliz kupon kumaşından yallah deyince altı takım elbise yaptırdı. Kemik gibi sert yakalıklar, kravat mıravat... Neme gerek benim İngiliz kupon kumaşı, kolalı yaka, kravat? Biz Anadolu çocuğuyuz arkadaş. Gavır icatlarının bize lüzumu yok. (Orhan Kemal, 2013b: 279). 


\section{ORUÇ, Osman (2020). "Orhan Kemal'in Bereketli Topraklar Üzerinde ve Gurbet Kuşları Adlı Romanlarında Taşralı İnsanın Değişim Süreci”, Mavi Atlas, 8(2): 507-516}

Karısının yokluğunda daima bulgur pilavı yemesi, gecelik entarisini giymesi onun taşralı tarafının şehirli olmaya karşı bu alttan alta direnişinin ifadesidir.

Pek sevdiğimden değil, benim hanımın, arkadaşlarının inadına. İnadına da değil, bulgur pilaviynan cacık, ayran bana İngiliz kuponundan elbiselerimi unutturuyor, kolalı yakamı, kravatımı unutturuyor da ondan! (Orhan Kemal, 2013b: 280).

Öte yandan İflahsızların Memed, Kastamonulu arkadaşının yardımıyla okuma-yazma öğrendikten sonra değişmeye başlar. Devamında onu politik bir duruş sergileme düzeyine erişmiş bir kimlikte görürüz. Menfaatleri uğruna iktidarın yanında yer alan türdeşlerinin aksine o, iktidarın karşısında bir konum belirler. Bu durum onun şahsiyetinin oluşumu bağlamında mesafe katettiğini; kendilik kodlarını baskılama ve kontrol altına alma niyetine karşı bireyliğini hayata geçirme ve bir başına mücadele kabiliyetine eriştiğini işaret eder. Patronunun Demokrat Parti'ye girme baskısına boyun eğmez, bu yüzden karısıyla yaşadığı köşkten ayrılmak zorunda kalır. Zeytinburnu'nda zar zor aldıkları arsaya gecekondu inşa etme sürecinde de iktidara karşı direnen, muhalif 'İşçi Memed'i görürüz. Böylece Sivaslı köylü Memed, "insanın kendi kendini gerçekleştiren özü" (Marx 1963'ten aktaran Swingewood, 2010: 67) olan emek aracıllğ̆1yla bir kimlik inşa eder, ekmeğini alnının teriyle kazanan emekçi 'İşçi Memed'e dönüşmüş olur.

İflahsızın Memed'in Kurulu düzenini yıkma pahasına, patronu ve babayı karşısına alması ve bir özne olarak politik duruşunu belirlemesi, onun keskin bir değişim/dönüşüm süreci içinde olduğunu; itaat eden bir kimliksizlikten başkaldıran bir kimliğe evrildiğini gösterir. Kente geldiği ilk zamanlarda, kendisinden önce kente gelenlere muhtaç konumda iken, zaman içinde emeğinin gücünü idrak eden ve bu anlamda işçi sınıfinın ideolojisine yaklaşan, "köylülükten proleterleşmeye yönelen" (Altuğ, 1974: 7) Memed son tahlilde bir özne oluşunun farkına varır. Nitekim "Marx, sınıfsal konumun, toplumsal yaşamı geniş kapsamlı bir biçimde belirlediğini, bireylerin bilinçlerine, ideolojik konumlanmalarına ve kültürel sermayelerini de içerecek biçimde kapitalist üretim ilişkilerinden neşet eden bir ilişkiler ağının ürünü olduğunu ifade eder" (Özkurt, 2018: 48).

Memed, İstanbul'a ayak bastığ1 ilk günlerde şehirliler tarafindan kendisine yöneltilen hakaretlere ses çıkarmaz, çıkaramaz. Ancak geçen zaman içinde Memed değişir, haksızlıklara, hakaretlere boyun eğmek yerine onlarla mücadele etmeyi yeğleyen bir birey haline gelir. Şehirlilerin kendisi ve kendisi gibi taşradan gelenlere yakıştırdıkları "sürü"nün bir parçası değildir. Haydarpaşa garında ailesini karşılamaya gittiği zaman yine bu hakaretlere maruz kalır, fakat bu defa susmaz.

'Ayılara hele ayılara!'

'Sürü, şerefsizim sürü!'

'...'

Memed zınk diye durdu. Bu türlü konuşmakta olan şehirlilere sertçe baktı:

'Ayı sizin gibi olur,' dedi. 'Neremiz ayı bizim?'

Şehirliler de durdular.

'Sana m1 söylüyoruz?'

'Sana ne?'

Memed gene dikildi:

'Onlara da söyleyemezsiniz!'

Ve bir zamanlar Kastamonulunun şehir uşaklarına söylediklerini olanca hıncıyla tekrarladı:

'Onlar da bu vatanin evladı!'

Matrak biri, 'Domates mi dedin?’ dedi.

'Domates dedim, yin mi? Domates miymiş. Ayı sizin gibi olur. Terbiyesizler!' (Orhan Kemal, 2013b: 261). 


\section{ORUÇ, Osman (2020). “Orhan Kemal'in Bereketli Topraklar Üzerinde ve Gurbet Kuşları Adlı Romanlarında Taşralı İnsanın Değişim Süreci”, Mavi Atlas, 8(2): 507-516}

İstanbul'a geldikten sonra Memed'in babası İflahsızların Yusuf, oğlundaki değişimi gözler ve bu değişimden rahatsızlık duyar. Artık karşısında eski Memed yoktur, 'Dırnaksız Memed' vardır.

İstanbul Memed'le babasını birbirinden sadece fiziki manada uzaklaştırmamış, onları zihniyet olarak da birbirinin yabancısı iki insan yapmıștır. Tıpkı Gafur'un Memed'e İstanbul'a geldiği ilk günlerde davrandığı gibi, Memed de köyden gelen babasına karşı ilgisiz, soğuk ve yer yer kafa tutan bir tavır takınmıştır. Bu tavır bir süre sonra bıkkınlık halini almış ve neticede baba ve oğul aynı çatı altında yaşayamaz olmuşlardır. Memed, mektup yollayarak ailesini İstanbul'a davet ettiğine pişman olur.

Baba maba... Biktım usandım be... (Orhan Kemal, 2013b: 319).

Bu kısa cümle esasen Memed'in babası Yusuf'la önceliklerinin, kıymet hükümlerinin, beklentilerinin artık kesişmediğini; aksine çatıştığını ifade eder. Memed, babasına,'emmisinden' tevarüs eden hayat görüşünü reddeder.

Öte yandan Memed'in kız kardeși Ümmü, bașta herhangi bir sosyal ortamda yanakları kızaran utangaç bir kişiliktir. İstanbul'a taşındıktan sonra saçlarını kestirir, komşu köşkün beyini baştan çıkaran hafif meşrep hizmetçisi Pervin gibi mahalledeki bakkalın çapkın çırağıyla yakınlaşır, onunla gönül eğlendirmeye başlar, hapisten çıkan Gafur da Ümmü'deki bu değişmeden nasiplenir. Ümmü o kadar değişmiştir ki, uzaktan akrabası Gafur onu ilk gördüğünde tanıyamaz. Zira o artık bir şehir kızı olmuştur.

Tam bu sırada içeriye Ümmü girdi. Saçları kısacık kesilmişti. Sırtında İstanbul kızlarını hatırlatan zarif poplin bir entari, ayaklarında yüksek topuklu ayakkabılar. Gafur baktı, taniyamadi. (Orhan Kemal, 2013b: 325).

Köyden kente göç eden aile bireyleri kentin çalışma koşulları, yeni hayat biçimi, şehirlilerle yaşadıkları uyumsuzluk/çatışma gibi nedenlerle çetin bir süreç yaşarlar. Bu süreçte aile bireyleri birbirlerinden uzaklaşırken, öte taraftan Kabzımal Hüseyin Korkmaz ve Gafur örneğinde olduğu gibi değer yargıları çöker. Kentin tüketemediği tek kişi, Memed'dir. O, emeğini devreye sokarak öz saygısını pekiştirir ve son tahlilde bilinçli bir birey kimliği elde ederek mücadelesini sürdürür. $\mathrm{Bu}$ anlamda kentte eylemleriyle adeta kendisini yeniden tasarlayan İflahsizın Memed 'varolurken', diğerleri bunu başaramadıklarından insanî erdemlerini yitirirler ve bir bakıma 'yok' olurlar.

\section{Sonuç}

Orhan Kemal'in romanc1 kimliğini tesis eden ve konusunu toprak ve fabrika işçilerinin hayat hikâyelerinden alan eserlerinden biri olan Bereketli Topraklar Üzerinde'de nesneleșen insanla karşılaşırız, buna mukabil Gurbet Kuşlarinda İflahsızın Memed örneğinde olduğu gibi sınıf bilincine erişmiş ve böylece özne olmayı başarmış bireyle karşılaşırız. Biri kapitalizm çarkının dişlilerinden biri olmayı gönüllü olarak kabul edip benimserken, diğeri bu gerçekliğe karşı savaş halindedir. $\mathrm{Bu}$ iki birey baba-oğuldur. Oğul, babanın kabullerini reddeder. Biri gerçeğe gözlerini kapama kolaycıllğına kaçıp kişiliksizleşirken, diğeri katı gerçeğe gözlerini açma cesaretini ve erdemini göstererek bir şahsiyet kazanır. Biri 'emmisinin' şark kurnazlı̆ı1 addedilebilecek öğütlerini rehber edinirken, diğeri babasına meydan okur. Toplumsal koşulların birbirine yabancılaştırdığı baba ve oğulun zihniyet bağlamında herhangi bir ortaklıkları kalmamıştır. Yusuf insanî özün rağmına, kendisine dayatılan ve maddi olana sahip olmakla anlam kazanan kimliğiyle var olurken/bir bakıma yok olurken; Memed büyük şehirde tecrübe ettiği hayattan öğrendikleriyle bir bilinç düzeyine yükselir ve son tahlilde hakiki anlamda bir birey olur. Yusuf, güç sahiplerine teslim olup "metanın mantığ tarafindan yönetilen bireysel ve toplumsal yaşamın" (Baudrillard, 2017: 250) güdülen bir figürü olmayı benimserken, Memed, babası da dâhil, güç sahiplerine direnerek, onlarla mücadele ederek şahsiyetini kurar. Babası Yusuf ve eski Kabzımal Hüseyin Korkmaz para ve onun getirileri karşısında eğilirler. Memed ise emeğe saygı duyması itibariyle onlardan ayrılır. 
ORUÇ, Osman (2020). “Orhan Kemal'in Bereketli Topraklar Üzerinde ve Gurbet Kuşları Adlı

Romanlarında Taşralı İnsanın Değişim Süreci”, Mavi Atlas, 8(2): 507-516

\section{Kaynakça}

ALTUĞ, Taylan (1974). "Orhan Kemal'in Romanc1luğ1 Üstüne Genel Notlar", Türkiye Defteri, (10): 6-9.

BAUDRİLLARD, Jean (2017). Tüketim Toplumu, çev. Nilgün Tutal-Ferda Keskin, İstanbul: Ayrıntı Yayınları. Kitap.

ECO, Umberto (2014). Düssman Yaratmak, çev. Leyla Tonguç Basmacı, İstanbul: Doğan Yayınlar1.

FETHİ NACİ (2012). Yüz Yılın 100 Türk Romanı. İstanbul: Türkiye İş Bankası Kültür Yayinlar1.

GIDDENS, Anthony (2016). Modernliğin Sonuçlar, çev. Ersin Kuşdil, İstanbul: Ayrıntı

GÜLTEKİN, Mehmet Nuri (2006). "Orhan Kemal'in Eserlerinde Modernleşme, Birey ve Gündelik Hayat", Sosyoloji Dergisi, (15): 119-128.

KURDAKUL, Şükran (2005). Cağdas Türk Edebiyatı 4, İstanbul: Evrensel Basım Yayın.

MORAN, Berna (2012a).Türk Romanına Eleștirel Bir Bakış 1, İstanbul: İletişim Yayınları.

MORAN, Berna (2012b).Türk Romanma Eleştirel Bir Bakış 2, İstanbul: İletişim Yayınları.

ORHAN KEMAL (2013a). Bereketli Topraklar Üzerinde, İstanbul: Everest Yayınlar1.

ORHAN KEMAL (2013b). Gurbet Kusslar, İstanbul: Everest Yayınları.

ÖZKURT, Cem (2018). Simf ve Ötesi, Ankara: Gece Kitaplığı.

PROPP, Vladimir (2017). Masalın Biçimbilimi, çev. Mehmet Rifat-Sema Rifat, İstanbul: Türkiye İş Bankası Kültür Yayınları.

SWINGEWOOD, Alan (2010). Sosyolojike Düş̈̈ncenin Kısa Taribi, çev. Osman Akınhay, İstanbul: Agora Kitaplığı. 